\title{
Bit error analysis of binary phase shift keying modulation over additive white gaussian noise channel using replica correlation detection
}

\section{Yenileme korelasyon tespiti kullanılarak toplanır beyaz gauss gürültülü kanal üzerinden ikili faz kaydırmalı anahtarlama modülasyonunun bit hata analizi}

\author{
Eren KÜREN ${ }^{*}$ (iD) , AkIn CELLATOĞLU⿱ \\ 1,2Department of Computer Engineering, Faculty of Engineering, European University of Lefke, Northern Cyprus, Turkey. \\ ekuren@eul.edu.tr, ecellatoglu@eul.edu.tr
}

Received/Geliş Tarihi: 04.05.2018

Revision/Düzeltme Tarihi: 14.03.2019

doi: $10.5505 /$ pajes.2019.06253

Accepted/Kabul Tarihi: 20.03.2019

Research Article/Arastırma Makalesi

\begin{abstract}
Replica correlation is performed for reaching better data transfer results in communication systems. The use of a pulse code signal pattern with replica correlation detection in a transmitted pulse packet is an important requirement to ensure high performance in noisy communication channels. In this paper, a BPSK modulation design with a system software is proposed to study the performance under varied noise inclusions in the system channels. Using this design, 7-cell and 9-cells replica correlation model are applied to get lossless data in communication systems. The results are produced to show the improved performance of the system in pulse type communication.
\end{abstract}

Keywords: BPSK, Gaussian, Replica, Correlation, Communication, Signal processing.

\section{Introduction}

In this work, the bit detection process has been analyzed over AWGN channel by using the pulse-coded detection model under varied noisy environments. Quality of data transmission is an important concern in communications systems with lossless data transmission. Several approaches have been attempted [1]-[4] in the past for reaching better performances in communications. Designed models with hardware controlled and software-controlled replica correlation detection have been reported [3]-[8]. In addition, replica correlation methods are generally used in radar and sonar systems and as well as in data communication systems. Specifically, a detector based on replica correlation was shown to result in an increase in SNR [9]-[14]. SDS (software-defined system) has been designed to increase the flexibility features of the system. The SDS is being reduced the complexity of the hardware wiring and the cost of the system. In hardware, the designer should design a new optimized circuit that will provide the processing required at the lowest possible power consumption [15],[16]. As a further attempt, SDS can be used as software in communication physical layers. For improving the design considerations of applying the replica correlation in communication systems a new model is designed. Performance of the system is analysed to get better performance and accurate data in communication systems over AWGN channel which is reported here.
Öz

Iletișim sistemlerinde daha iyi veri aktarım sonuçlarına ulașmak için yenileme korelasyonu uygulanmıştır. İletilen darbe paketinde çoğaltma korelasyon tespitine sahip bir darbe kodlu sinyal örüntüsü kullanılması, gürültülü iletişim kanallarında yüksek performans sağlanmasını sağlayan önemli bir gerekliliktir. Bu yazıda, bir sistem yazılımı ile bir BPSK modülasyon tasarımı, kanallardaki çeşitli gürültülü ortamlar altında performansı incelemek için önerilmiștir. Bu tasarımı kullanarak, iletișimde kayıpsız veri elde etmek için 7 hücreli ve 9 hücreli çoğaltma korelasyon modeli uygulanmaktadır. Darbe tipi iletișim sistemlerinde sistemin gelișmiș performansını gösteren sonuçlar üretilmiștir

Anahtar kelimeler: BPSK, Gauss, Replika, Korolasyon, İletişim, Sinyal ișleme.

\subsection{BPSK the Binary phase shift keying Modulation}

In BPSK the phase of a carrier is changed between two values. in accordance with the binary signal level. The information about the bit stream is contained in the phase changes of the transmitted signal. For instance, the levels are denoted to transmit the signals " 0 " and " 1 ". The symbol-mapping table encodes bits $(b n) 1$ and 0 to transmission symbols (an) 1 and -1 , respectively. The nature of the continuous wave (CW) signal, which is BPSK keyed and transmitted according to cell pattern is presented in Figure 1.

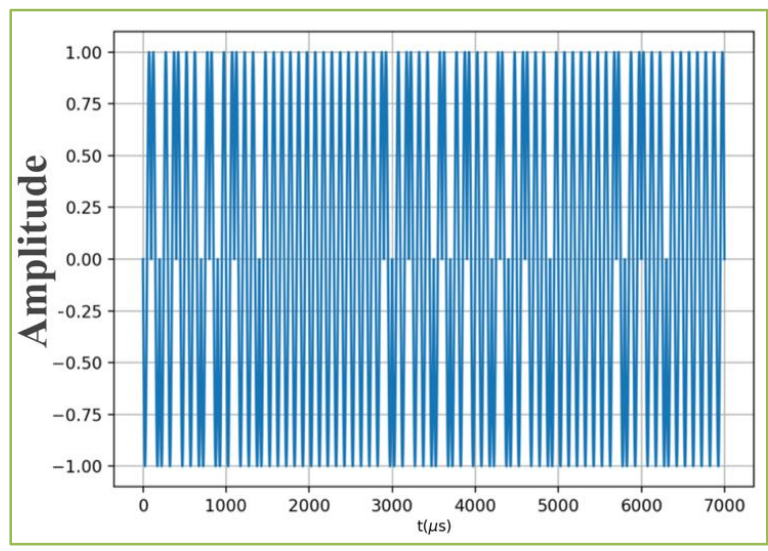

Figure 1. CW Waveform in $R C(7)$ cell pulse packet.

${ }^{*}$ Corresponding author/Yazıșılan Yazar 
In every $\mathrm{Tb}$ seconds the modulator transmits one of the two carrier bursts that corresponds to the information bit being a 1 or 0 . Multiplying a sinusoid by negative one is the same as inverting it [16],[17]. This leads to the possibility of implementing BPSK using the basic hardware configuration shown in Figure 2. BPSK BER is calculated by equation (1) and is experimented in AWGN channel [15].

$$
\begin{gathered}
P_{e}=\frac{1}{\pi} \int_{0}^{\frac{\pi}{2}} I(\bar{\gamma}, g, \theta) d \theta \\
g=1
\end{gathered}
$$

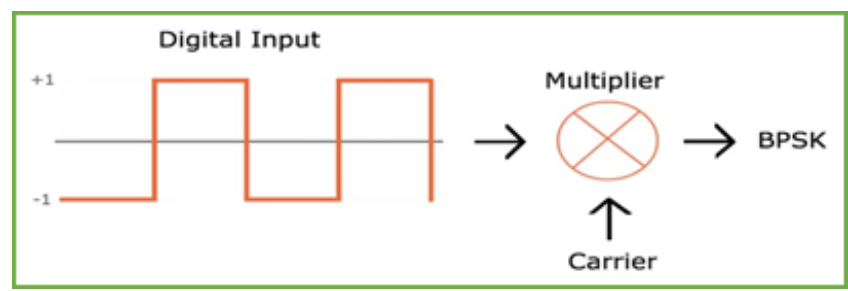

Figure 2. Basic hardware configuration.

\subsection{Replica correlation ( $R C$ ) detection process}

In order to explain our proposal, here is the definition of a known replica correlation process. Replica correlation technique is used in signal detection process for improving the probability of detection. This technique involves in using binary phase shift keyed signal as a packet combined in the duration of the on-going pulse. For simplicity in illustration, a 7-cell pattern is considered here. The phase shift pattern grasped for 7 -cells packet is $\{-1+1-1-1+1+1+1\}$ where +1 indicates in phase and -1 indicates out phase incurring a phase shift of $180^{\circ}$. Figure 3 shows the pattern of phase shift keyed signal [18] present during the pulsing period.

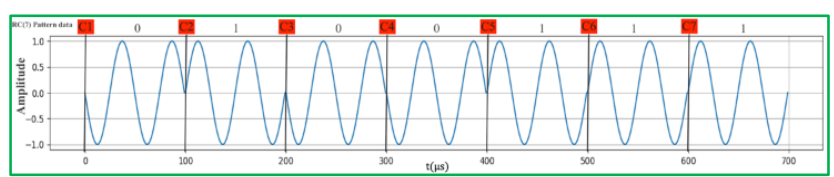

Figure 3. Replica Correlation Coded binary phase shift keying; $7 \Delta \mathrm{T}$-Cell period.

Samples of received signal pass to a digital delay line [5] with taps located at seven regular intervals. Inversion of analogue signals at taps 4,5 and 7 takes place to boost the analogue signal. This is presented in the reverse order $\{-+--+++\}$ of the transmitted pattern. When the incoming signal reaches the last cell, at the instant of traversing it, the signal is boosted up 7 times of the original amplitude. Figure 4 shows replicacorrelated output. Also, Figure 5 illustrates that the other optimal cell pattern which has 9 cells $\{+++--++-+\}$ [4]. Cells' voltage is calculated by (2). 9-cells voltages $K_{i}$ are $\{-1,0,-1,0$, $-1,0,3,0,9\}$. The target is detected by comparing the signal amplitude with an appropriate threshold.

$$
K_{i}=\sum_{n=1}^{i} p_{n} x_{(i+1-n)}
$$

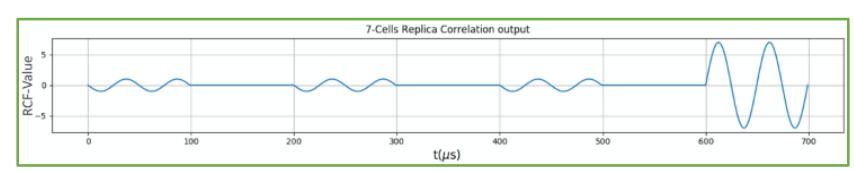

Figure 4. $R C(7)$ cells replica correlated output.

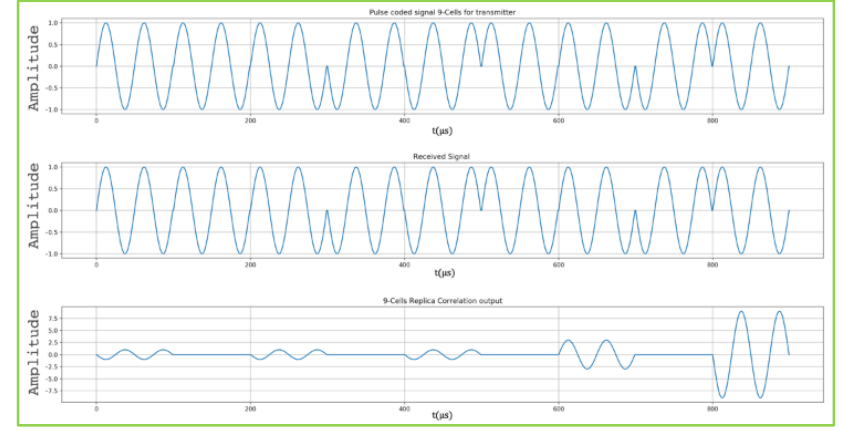

Figure 5. Optimal $R C(9)$ cells pattern replica correlation.

\section{Process model function}

\subsection{Using replica correlation in data transmission}

Time duration of each bit is known. In this bit duration, we incorporate the 7-cells pattern for performing replica correlation. (1011000) (1: - out phase; $0:+$ in phase). Here, applying replica correlation to digital data bits is detailed out. The 7-cell pattern of replica correlation is applied to the system's physical layer for determining the bits. Figure 6 illustrates how to apply $R C$ pulse coded model [3] to original signal. Figure 7 shows hardware scheme for applying $R C$ and recovering of signal after $R C$ detection.

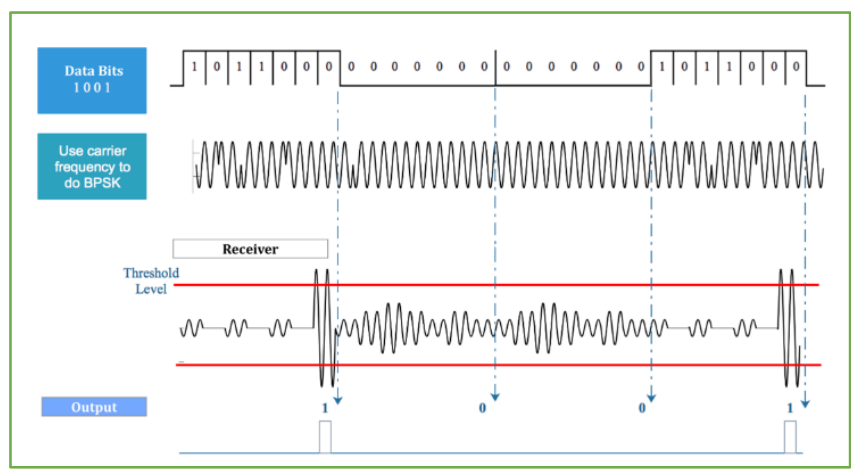

Figure 6. Applying replica correlation $(R C)$ pulse code for channel.

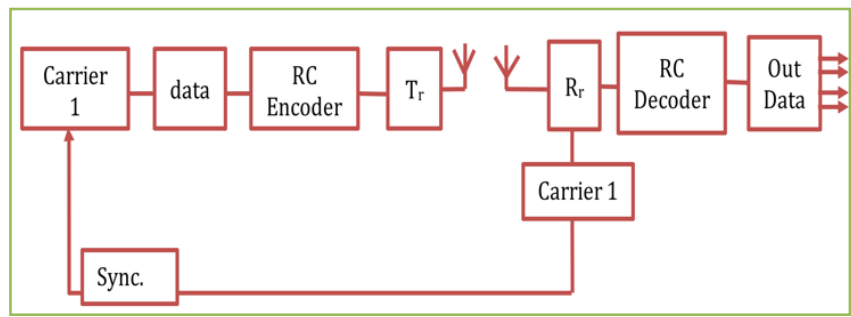

Figure 7. Replica correlation $(R C)$ pulse code block scheme.

Herein, the $R C$ Encoder generates BPSK signal for data bit. After BPSK signal data, if the data bit is 1, 7-cells replica correlation pattern is produced for it. Then after carrier modulation the transmitter sends data to destination receiver. When the receiver gets pulses, replica demodulator converts the received pulses to be ready for $R C$ detection. Finally, $R C$ decoder gets the bits to produce the lossless output data. 


\section{Result and simulation}

\subsection{AWGN channel design}

In this study, custom AWGN noise is developed by using python programming language, which is a good programming language. It has many useful libraries to develop applications [19]. Our custom function to add AWGN noise to BPSK replica correlated signal is being explained. The AWGN function design involves in four sequence operations called as steps. In step 1 , calculation of the power in the vector $x$ is done. In step 2 conversion of $S N R_{d b}$ value to linear scale $S N R_{\text {lin }}$ is performed.

$$
E_{S}=\frac{1}{L} \sum_{i=0}^{L-1}\left|x[i]^{2}\right| ; \text { where } L=\text { length }(x)
$$

$$
n=\left\{\begin{array}{c}
\sqrt{\frac{E_{S}}{S N R_{\text {lin }}}} * \text { randn }(1, L) \\
\text { if } x \text { is real. } \\
\sqrt{\frac{E_{S}}{S N R_{\text {lin }}}} *[\operatorname{randn}(1, L)+j * \operatorname{randn}(1, L)] \\
\text { if } x \text { is complex. }
\end{array}\right.
$$

In step 3 we find the noise vector using equation (4). Finally, in step 4 noise vector is added to the BPSK signal $x$ as in equation (5) [20].

$$
y=x+\text { noise }
$$

Figure 8 gives actual codes of the AWGN noise generator function and Figure 9 shows the output of the custom AWGN function with the sawtooth waveform in python. The function is benchmarked with matlab built-in AWGN function which is shown in Figure 10.

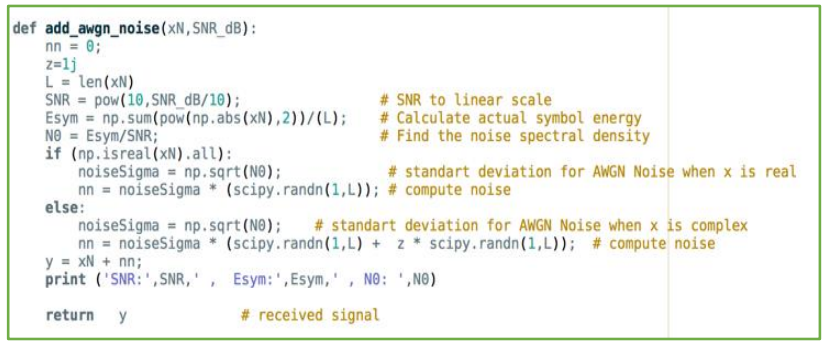

Figure 8. Custom AWGN function in python.

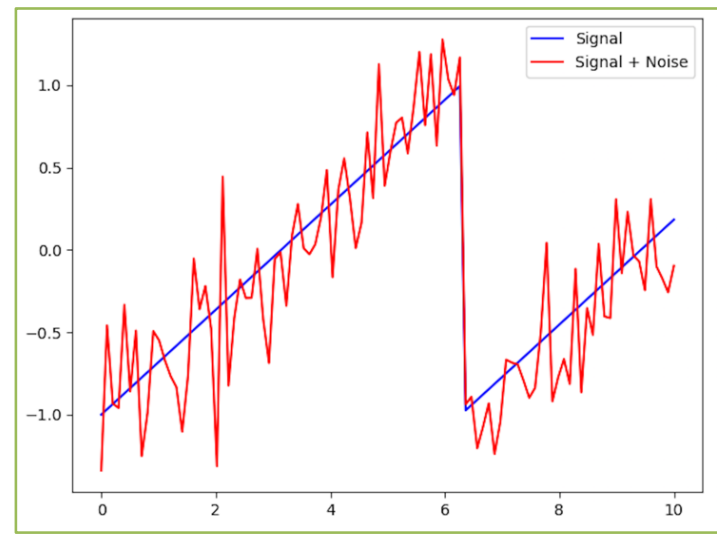

Figure 9. Sawtooth waveform with custom AWGN noise function in python $\mathrm{SNR}_{\mathrm{db}}=5$.

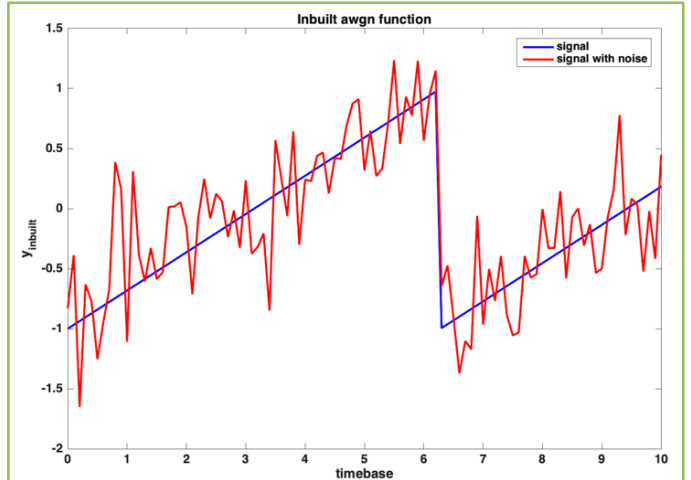

Figure 10. Sawtooth waveform with Matlab built-in AWGN noise function $\mathrm{SNR}_{\mathrm{db}}=5$.

\subsection{Performance analysis}

The probability of detection depends on the probability of false alarm and the signal to noise ratio [7] of received signal. Moreover, the level of the received signal plus noise depends on the number of cells $n$ present in the transmitted pulse packet. The relationship between the probability of detection and result is almost linear.

\subsection{Detection process}

The threshold process function is calculated with equation (6) and equation (7) for symbol detection. Absolute values of $C_{i}$ (Cell) signal is divided by $\mathrm{N}-1$. Total of all values is the threshold value of symbol 0 . The absolute value of the last cell signal is divided by the number of cells $(\mathrm{N})$ to find the symbol 1 threshold value. Therefore, detecting the desired bit on a threshold would be easy [21],[22]. The symbol decision process is doing with the comparison of the two threshold values. Then, whichever has the maximum threshold, it is selected.

$$
\begin{aligned}
\text { Threshold }_{0} & =\sum_{i=0}^{N-1} \frac{\left|C_{i}\right|}{N-1} \\
\text { Threshold }_{1} & =\left|C_{N}\right| / N
\end{aligned}
$$

The detection process selection is shown in Figure 11. The following performances are estimated based on random generated bits data.

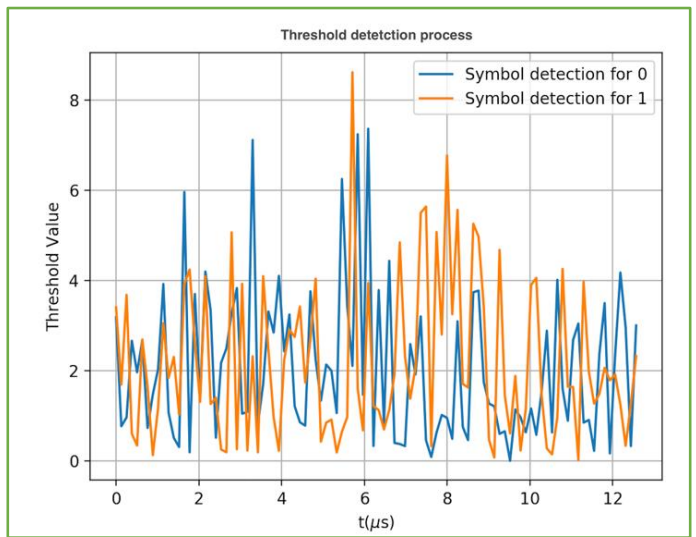

Figure 11. Symbol analysis of $R C$ threshold detection.

\subsection{Performance analysis under noisy environment}

The performance analyzer software is written by python programming language and matlab. Figure 12 shows that 
theoretical bit error rates. The software simulation has provisions to add different levels of noise and assess the performance of replica correlation method.

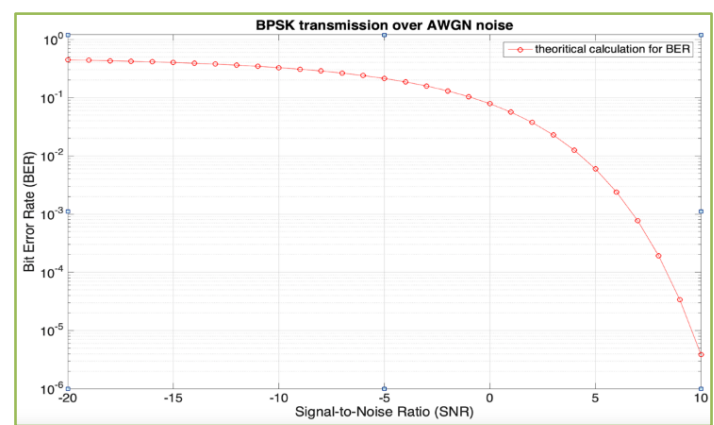

Figure 12. Theoretical BPSK modulation over AWGN channel by using monte-carlo simulation in matlab.

Figures 13 to 15 illustrate the performance and BER (Bit Error Rate) estimation under noisy environment for 7-cells pattern replica correlation. Varied $S N R_{d b}$ adds additive white gaussian noise to original signal and performance is evaluated [23]-[26].

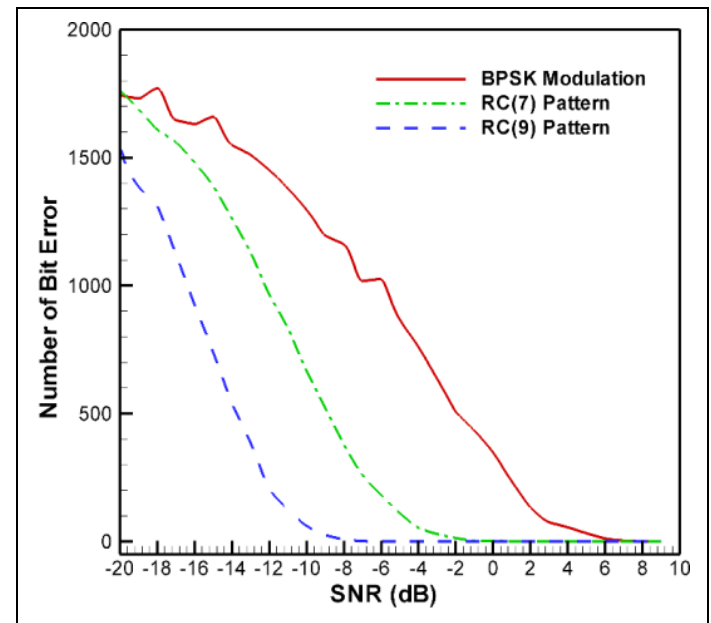

Figure 13. $R C(7)$ cells and $R C(9)$ patterns and BPSK modulation over AWGN channel using Replica correlator. Simulated with 4000 bits.

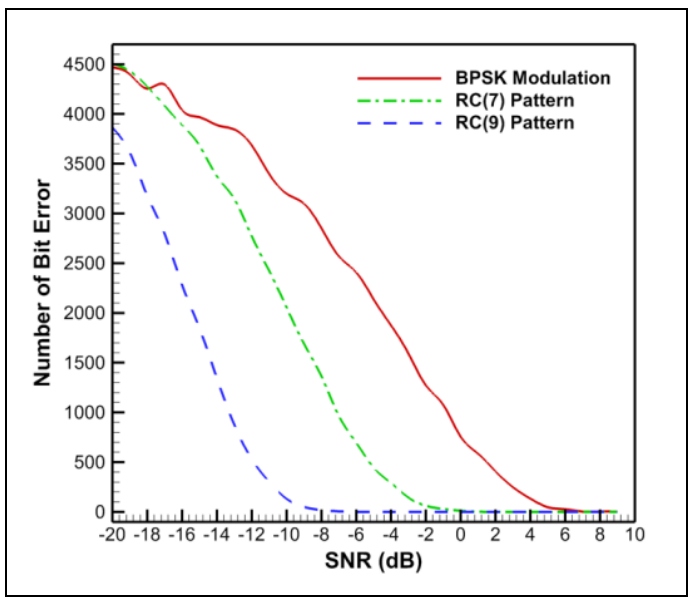

Figure 14. $R C(7)$ cells and $R C(9)$ patterns and BPSK modulation over AWGN channel using Replica correlator. Simulated with 10000 bits.

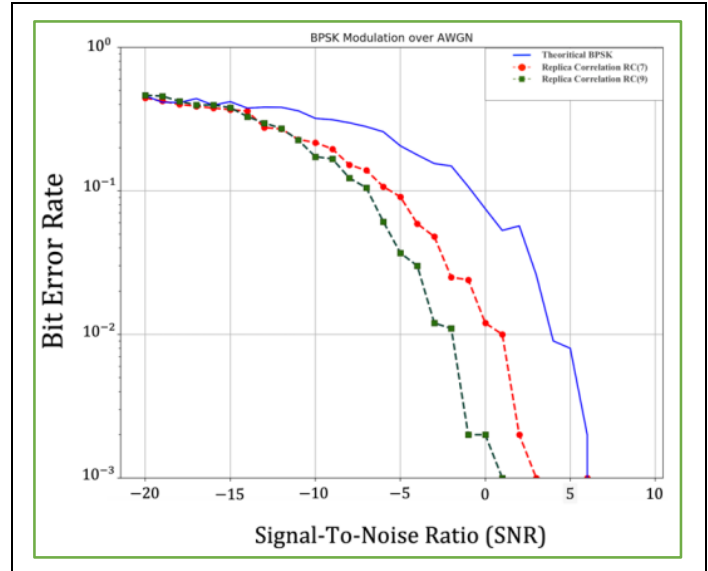

Figure 15. BPSK modulation comparison with $R C(7)$ and $R C(9)$ pattern BER analysis.

In the evaluation process correlation is applied into channel and the bits are transmitted to receiver. Improvement of the probability of detection is estimated with our evaluation as proved by test results. The simulated bits are increased in steps at levels of 4000 and 10000 bits using $R C(7)$ cells pattern and $R C(9)$ cells pattern. Then the results obtained are shown in the Figure 13 and Figure 14. The proposed model shows much lower bit loss error compared to previous results. This proves clearly that our system works well under the noisy environments.

Furthermore, the test is extended with 9-cells $R C$ pattern. For this test the bits size is kept at 4000 and 10000 . The SNRdb is ranging from -20 to +10 . Figure 18 and Figure 19 show the test results and proves better performance.

BER analysis of patterns and comparisons has been evaluated. Figure 20 illustrates the comparison of BER analysis of BPSK, Replica correlation $R C(7)$ and $R C(9)$ coded signals in AWGN channel bit error rates.

\section{Conclusion}

An analysis of simulation results reported here shows better performance by using replica correlation in pulse type communication systems. Transmitted bits are received with less data bit errors. The 7-cell pattern would be useful in all works involving replica correlation as it is simple and easy to use. The bits lost in data transmission over AWGN channel using RC method, for different transmitted bits size on varied SNR values is shown to be less. Moreover, the bit loss in the BPSK modulation system tested by other $R C(9)$ cells pattern for varied SNR in AWGN channels is shown to be a bit less. As a result, transmission with more cells pattern yields relatively better performance. Therefore, different pulse type systems working under varied noisy environments can use $R C$ for improving probability of bit detection. The simulation program results presented here ensures the applicability of the technique in various bit transmission systems. The $R C$ model accommodates readily to various data communication systems for getting more accurate data transmission over noisy channels.

\section{References}

[1] Ingle VK, Proakis JG. Digital signal processing using MATLAB: A Problem Solving Companion. $3^{\text {rd }}$ ed. London, England, Cengage Learning, 2016. 
[2] Sarkar N. Elements of Digital Signal Processing. New Delhi, Indian, Khanna Publishers, 2004.

[3] Kuren E, Cellatoglu A. "Replica correlation detection in pulse code modulation system and performance analysis of bit detection". International Journal of Computer Science and Information Security, 15(5), 175-184, 2017.

[4] Kuren E, Cellatoglu A. "Optimal cell-pattern setting algorithm for communications systems". Electronics World, 123(1977), 32-34, 2017.

[5] Balasubramanian K, Cihan C. "An intelligent digital delay line for replica correlation". Proceedings of the International Conference on Robotics Vision and Parallel Processing for Industrial Automation, Malaysia, 26 -28 May 1994.

[6] Balasubramanian K."Binary phase shift keying generator". Electronics World, 104(1744), 300-300, 1998.

[7] Balasubramanian K, Camur B. "On the development of replica correlation software for improving the probability of detection". Proceedings of the $6^{\text {th }}$ World Multi Conference on Systemics, Cybernetics and Informatics, Orland, Florida, USA, 14-18 July 2002.

[8] Taub and Schilling. Principles of Communication Systems. New Delhi, Tata Mc-Graw Hill, 2000.

[9] Klay J, Mellinger DK, Moretti DJ, Martin SW, Roch MA. "Advanced methods for passive acoustic detection, classification, and localization of marine mammals". Naval Undersea Warfare Center Div Newport RI, Fort Belvoir, USA, 2013.

[10] Po K, Takada JI. "Signal detection for analog and digital TV signals for cognitive radio". IEICE Technical Report, Tokyo, Japan, 2006.

[11] Glisson T, Black C, Sage A. "On digital replica correlation algorithms with applications to active sonar". IEEE Transactions on Audio and Electroacoustics, 17(3), 190-197, 1969.

[12] Knight WC, Pridham RG, Kay SM. "Digital signal processing for sonar". Proceedings of the IEEE, 69(11), 1451-1506, 1981.

[13] Glisson TH, Black CI, Sage AP. "On sonar signal analysis". IEEE Transactions on Aerospace and Electronic Systems, (1), 37-50, 1970.
[14] Zou L, Haah J. "Spurious long-range entanglement and replica correlation length". Physical Review B, 94(7), 075151-17, 2016.

[15] Rondeau TW, Bostian CW. Artificial Intelligence in Wireless Communications. London, Artech House, 2009.

[16] Abdo-Tuko M. "Performance evaluation and comparison of different transmitter detection techniques for application in cognitive radio". International Journal of Networks and Communications, 5(5), 83-96, 2015.

[17] Sönmez M, Akbal A. "Yeni bir BPSK modülatörün tasarımı". Pamukkale Üniversitesi Mühendislik Bilimleri Dergisi, 23(5), 492-496, 2017.

[18] Balasubramanian K. "Replica correlation detection". Electronics World, 106(1767), 238-240, 2000.

[19] Beazley DM. Python Essential Reference. $4^{\text {th }}$ ed. USA, Addison-Wesley Professional, 2009.

[20] Mathuranathan Viswanathan. "How to generate AWGN noise in Matlab/Octave (without using in-built AWGN function)".

https://www.gaussianwaves.com/2015/06/how-togenerate-awgn-noise-in-matlaboctave-without-using-inbuilt-awgn-function (15.06.2015).

[21] Kennedy G, Devis B. Electronic Communication Systems. $4^{\text {th }}$ ed. Tata, McGraw Hill, 1999.

[22] Grigorakis A. "Application of Detection Theory to the Measurement of the Minimum Detectable Signal for a Sinusoid in Gaussian Noise Displayed on a Lofargram". Aeronautical and Maritime Research Laboratory, Melbourne, Australia, 1997.

[23] Lee JS, Miller LE. CDMA Systems Engineering Handbook, Artech House Inc. 1998.

[24] Proakis JG, Salehi M. Communication Systems Engineering, New Jersey, USA, Prentice Hall, 2002.

[25] Chaudhary S, Gupta V, Dwivedi VK. "Performance comparison of BPSK in rayleigh and AWGN channel by Monte Carlo simulation method". IEEE $6^{\text {th }}$ International Conference on Information Technology New Generations ITNG'09, Las Vegas, NV, USA, 27-29 April 2009.

[26] Meghdadi V. "BER calculation". https://www.unilim.fr/pages_perso/vahid.meghdadineyshabouri/notes (2008). 